\title{
The Tramway Concession of Jerusalem, 1908-1914: Elite Citizenship, Urban Infrastructure, and the Abortive Modernization of a Late Ottoman City
}

\author{
Sotirios Dimitriadis
}

In January 1909, a group of Jerusalem businessmen and notables representing the Jerusalem Chamber of Commerce and the recently founded Banque commerciale de Palestine submitted a proposal for the construction of a tram system to the region's Ottoman authorities. The project contained plans to build an electrical tramway line that would link the historical walled core of the city to the residential neighborhoods that were beginning to emerge in the surrounding countryside. The petitioners' plans soon expanded to include provisions for the construction of a second tramway in the port city of Jaffa. The authorities were asked to draft a concession that would enable them to initiate work on these two lines. By providing transportation to the public of the two cities, the project aimed to expedite a process of urban expansion that had been gaining momentum since the end of the nineteenth century. The prospective investors, a cross-section of Jerusalem's local elites, were fully aware of how the introduction of modern infrastructure had benefitted other Ottoman cities; from the imperial capital in Istanbul to the nearby regional centers of Beirut, Damascus, and Aleppo. They seemed committed to endow their own city with a clear symbol of modern urban life. In the end, however, raising the necessary capital proved beyond the capabilities of the concessionaires, and the plans were eventually shelved by the outbreak of World War I.

Despite its eventual failure, this vignette from the history of late Ottoman Jerusalem could offer insight into the city's development during the period in question. The construction of urban infrastructure played a crucial role, both symbolically and materially, in the modernization of late Ottoman cities. This chapter will showcase the abortive project of the Jerusalem tramway and will place the city firmly within the framework of late Ottoman urban history. By examining the actors that mobilized in support of the project as well as highlighting the interplay between local elites and Ottoman administrators, I intend to study advancements in Jerusalem against the backdrop of developments that occurred during the period in other comparable Ottoman provincial capitals. My aim is to trace the elements, discourses, and practices

(C) SOTIRIOS DIMITRIADIS, 2018 | DOI:10.1163/9789004375741_030

This is an open access chapter distributed under the terms of the prevailing CC-BY-NC-ND License at the time of publication. 
that constituted the specific model of late Ottoman urban development. I do not intend to present an image of failed or uneven modernization, but rather to highlight the historical limits of that same model.

\section{Archives of Ottoman Citadinité}

Like other contributions to this volume, my chapter is structured around the critical application of the methodological aspirations of the field of Ottoman and Mediterranean urban history. With scholarship moving away from the macroeconomic inquiries of the center-periphery school, the study of the cities of the region has largely focused on the arrangements that sustained their diverse environments. Such arrangements included the connection between confessional communities and state institutions, relations among urban elites that transcended the sectarian divide, the steady flow and accommodation of rural migrants, and, in the late Ottoman period, the impact of the Tanzimat reforms and of the European presence. While I look at urban development in late Ottoman Jerusalem through the actions of the city's elites and the local authorities, my approach is informed by the debate around the analytical category of citadinité, a term that points to the significance of urban citizenship, formally and informally defined, in the evolution of eastern Mediterranean cities at the turn of the century. ${ }^{1}$ The concept pertains generally to the web of social practices that constitute citizenship in the Ottoman and Mediterranean contexts, and specifically to the emergence of a sense of urban identity among local notables and officials, structured around urban governance and the provision of services to the public. ${ }^{2}$

More recently, scholars have increasingly focused on the elements of ethnic rivalry, class exclusion, and political contestation, which were inherent to and defined the performance of Ottoman-Mediterranean citadinité. $^{3}$ From that critical perspective, the unsuccessful attempt to construct a tram in Jerusalem

1 See, for example, Robert Ilbert's seminal monograph, Alexandrie 1860-1960: histoire d'une communauté citadine (Cairo: Institut français d'archéologie orientale, 1996), or Mohamed Naciri's earlier "Regards sur l'évolution de citadinité au Maroc," in Middle Eastern Cities in Comparative Perspective: Points de vue sur les villes du Maghreb et du Machrek, ed. Kenneth Brown et al. (London: Ithaca, 1986).

2 Isabelle Berry-Chikhaoui, "Les notions de citadinité et d'urbanité dans l'analyse des villes du monde arabe," Les Cahiers d'EMAM, no. 18 (2009).

3 Malte Fuhrmann, "Cosmopolitan Imperialists and Ottoman Port Cities: Conflicting Logics in the Urban Social Fabric," Cahiers de la Méditerranée, no. 67 (2003). 
on the eve of World War I is indicative of the constitution of the city's elites, the conduits through which they mobilized, and the strategies that they employed. The history of late Ottoman infrastructure demonstrates how elite solidarity and the sense of local citizenship were founded on a commitment to a process of urban transformation modelled after western Europe. Conversely, the eventual failure of the project not only highlights the inherent contradictions of late Ottoman urban elite politics - the rivalries, competing networks, and conflicting strategies that defined the performance of citadinité - but also reveals their relative weakness vis-à-vis external actors.

The plans for the construction of the tram in Jerusalem and Jaffa has left documentary traces spread throughout the Ottoman archives in Istanbul. This chapter is specifically based on the correspondence between the notables and businessmen associated with the Jerusalem Chamber of Commerce and the Banque commerciale de Palestine, on the one hand, and the provincial and central Ottoman authorities, on the other. These documents, along with two maps of the environs of Jerusalem and of Jaffa which sketch the proposed route of the tramlines (figs. 24.1 and 24.2), are preserved in the largely uncatalogued archives of the Ottoman Ministry of Commerce and Public Works (Ticāret ve Nāfía Nezāreti). ${ }^{4}$ I came across this material while working through the archive as part of a broader study of the history of late Ottoman infrastructure. This chapter will also serve as a small demonstration of the utility of this archive for late Ottoman urban history, and specifically for the history of late Ottoman Palestine and Jerusalem.

\section{Projects of Modern Infrastructure in the Ottoman Reform Era}

Proposals like the one concerning the tramlines of Jerusalem and Jaffa were typical for Ottoman cities at the turn of the twentieth century, when both the Ottoman authorities and local elite were preoccupied with the transformation of the cityscape in line with contemporary European standards. Technical modernization had been one of the priorities of Ottoman statesmen ever since the launch of the Tanzimat reforms in the late 183os. Mehmet Ali Pasha's Egypt demonstrated the beneficial effects of technological innovation not only on agricultural production and commerce, but also on the ability of the central state to facilitate its control over its territories. The Ottoman state elites were

4 For the history of the ministry and information on its archive, see Yusuf Sarmay et al., Başbakanlık Osmanlı Arşivi Rehberi [Guidebook to the Ottoman State Archives] (Istanbul: Başbakanlık Devlet Arşivleri Müdürlüğü, 2010), 240-42. 


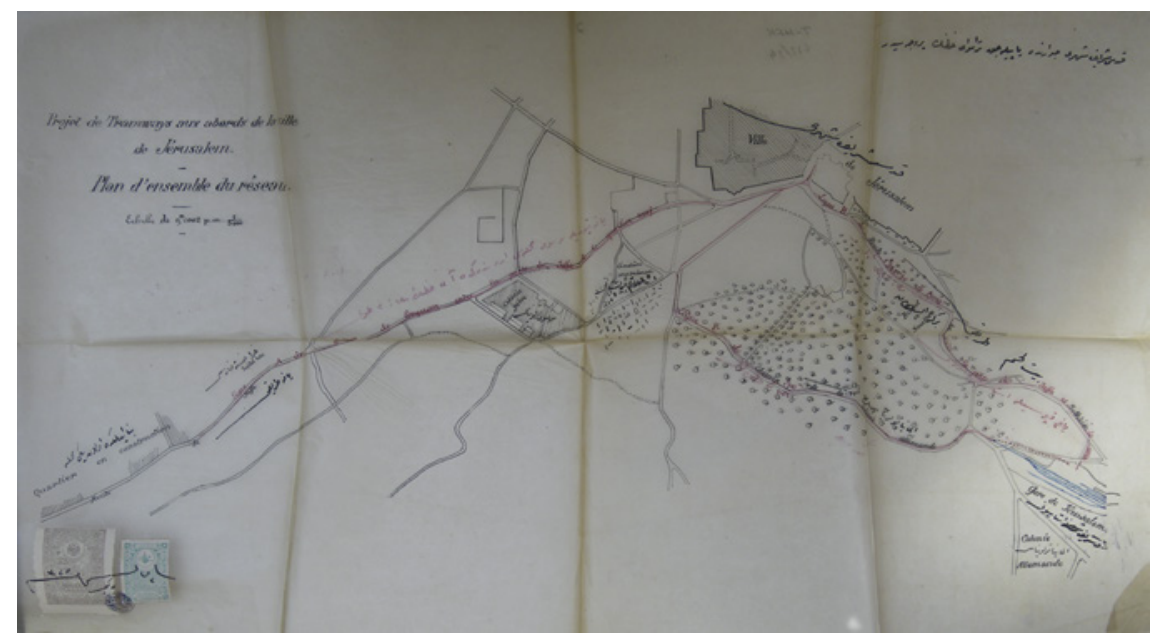

FIGURE 24.1 Tramway project for the suburbs of Jerusalem: outline of the network. OTTOMAN STATE ARCHIVES (BOA), T.HFN 693/34.

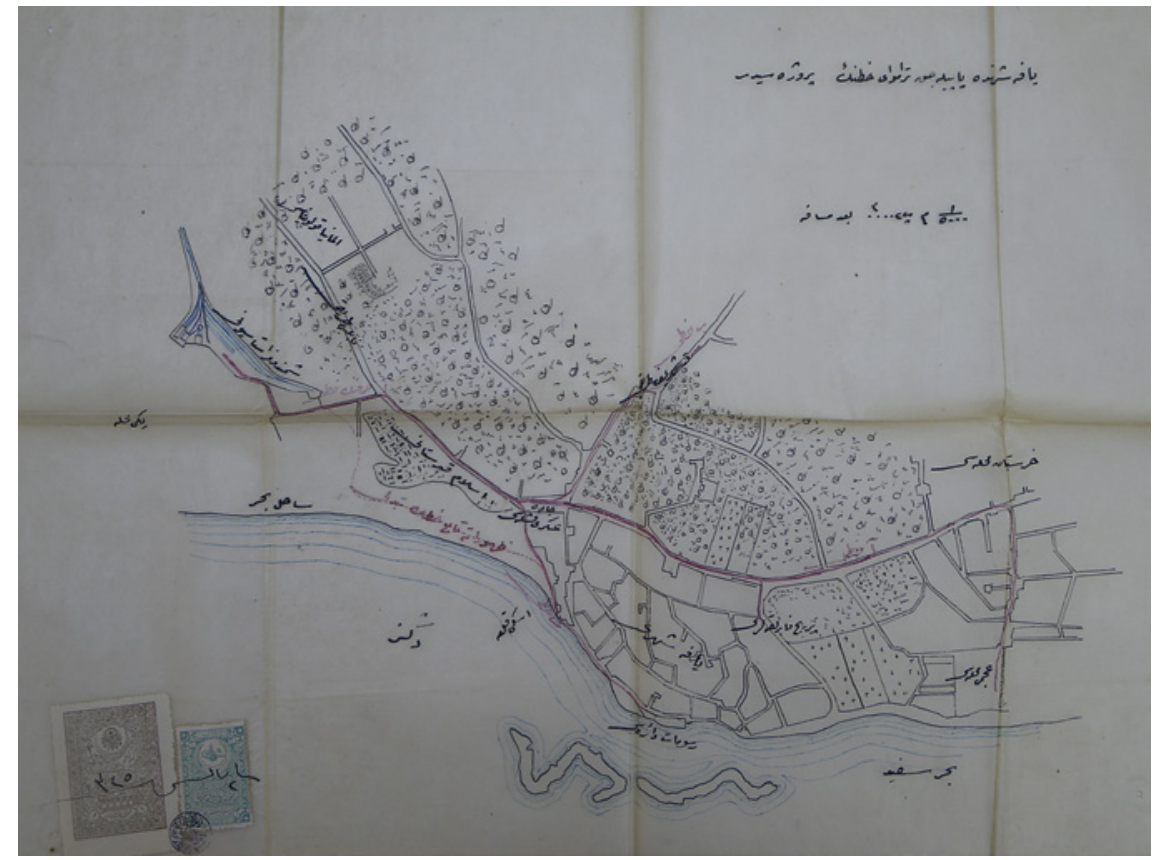

FIGURE 24.2 Plan of the tramline to be constructed in the city of Jaffa. OTTOMAN STATE ARCHIVES (BOA), T.HFN 693/34. 
therefore prepared to offer generous terms in order to attract foreign investments. European engineers courted members of the Ottoman administration and secured concessions to several grand public works projects. ${ }^{5}$ Soon, construction began on the first Ottoman railways in western Anatolia and the Balkans. ${ }^{6}$ In the end, however, expectations built around each of these projects proved overly optimistic. The Ottoman economy proved structurally unable to take full advantage of the potential of the new infrastructure networks. The costs of construction, exacerbated by the need to import almost all materials and most of the labor involved in the projects, far outweighed the modest economic benefits, contributing directly to the Ottoman default of 1875 . The restructuring of the empire's debt under international supervision, which followed the Ottoman defeat in the $1877-78$ war against Russia, allowed public investment in infrastructure to resume by the late 1880 s. $^{7}$

By that point, the Ottomans had taken measures to formalize the drafting process and awarding of concessions. Contracts were negotiated and closely contested between different branches of the imperial government and competing investors, who routinely secured the backing of their respective governments. ${ }^{8}$ For the European powers that were economically and diplomatically active in Ottoman Palestine and the Levant, the strategic value of their control over Ottoman transportation was seen as crucial for their imperial ambitions. Concessionaires attempting to rouse the interest of investors in their projects in the region routinely touted their potential for colonial expansion, as well as their beneficial impact on missionary activity and the traffic

5 For the history of the diffusion of modern technology and its unexpected consequences, see Daniel R. Headrick, The Tentacles of Progress: Technology Transfer in the Age of Imperialism, 1850-1940 (Oxford: Oxford University Press, 1988); also Timothy Mitchell, Rule of Experts: Egypt, Techno-politics, Modernity (Berkeley: University of California Press, 2002).

6 Donald Quataert, "Limited Revolution: The Impact of the Anatolian Railway on Turkish Transportation and the Provisioning of Istanbul, 1890-1908," in Workers, Peasants and Economic Change in the Ottoman Empire, 1730-1914 (Istanbul: Isis, 1993), 64-66; Basil C. Gounaris, Steam over Macedonia, 1870-1912: Socio-economic Change and the Railway Factor (Boulder: East European Monographs, 1993).

7 Edhem Eldem, "Ottoman Financial Integration with Europe: Foreign Loans, the Ottoman Bank and the Ottoman Public Debt," European Review 13, no. 3 (2005). For a comparative perspective from Egypt, see David S. Landes, Bankers and Pashas: International and Economic Imperialism in Egypt (London: Heinemann, 1958).

8 Faruk Tabak, "Imperial Rivalry and Port-Cities: A View from Above," Mediterranean Historical Review 24, no. 2 (2009). 
of visitors and pilgrims. ${ }^{9}$ Conversely, the Ottoman government, also aware of both the strategic and economic significance of modern infrastructure, used the process of awarding concessions as a means to balance out the influence of the competing European powers while minimizing the cost to the state treasury. The need for balance was perhaps greater than elsewhere in Ottoman Palestine. Over the course of the nineteenth century, the Ottoman rule in this region faced a series of challenges including foreign economic encroachment, Great Power rivalry, and an increase in the number of Christian and Jewish migrants.

\section{Jerusalem and Palestine in the Nineteenth Century}

In the early nineteenth century, Jerusalem was a small provincial town of about ten thousand inhabitants, its size constrained by its walls. Its urban economy and daily life were directly aligned to the peasant and nomadic societies of the surrounding region. However, by the eve of World War I, the city had emerged as an Ottoman provincial center; its population growing to around seventy thousand inhabitants..$^{10}$ The city had benefited greatly from the reorganization of the region's administration and its establishment as the seat of an independent district (mutașsarıflik) in $1872-74 .^{11}$ That development formally established the city as the administrative capital of a region increasingly integrated with the wider world. ${ }^{2}$ Accelerating trends that were already extant in

Anthony S. Travis, On Chariots with Horses of Fire and Iron: The Excursionists and the Narrow Gauge Railroad from Jaffa to Jerusalem (Jerusalem: Hebrew University Magnes Press, 2008), 107-11, highlights the use of religious imagery in the promotion of the JaffaJerusalem Railway among French investors.

10 Kemal H. Karpat, Ottoman Population, 1830-1914: Demographic and Social Characteristics (Madison: University of Wisconsin Press, 1985), 184-85, 222-23.

11 Alexander Schölch, Palestine in Transformation, 1856-1882: Studies in Social, Economic and Political Development, trans. William C. Young and Michael C. Gerrity (Washington, DC: Institute for Palestine Studies, 1993), 13-15; Butrus Abu-Manneh, "The Rise of the Sanjak of Jerusalem in the late 19th Century," in The Palestinians and the Middle East Conflict, ed. Gabriel Ben-Dor (Ramat Gan: Turtledove, 1978).

12 There is a vast literature on the history of late Ottoman Palestine, whose overview far exceeds the scope of this chapter. Besides Schölch, a selective list of monographs published in English could include Beshara Doumani, Rediscovering Palestine: Merchants and Peasants in Jabal Nablus, 1700-19oo (Berkeley: University of California Press, 1995); Yuval Ben-Bassat and Eyal Ginio, eds., Late Ottoman Palestine: The Period of Young Turk Rule (London: I. B. Tauris, 2011); and Abigail Jacobson, From Empire to Empire. Jerusalem Between Ottoman and British Rule (Syracuse: Syracuse University Press, 2011). 
the late eighteenth century, the policies of the Egyptian administration of the 1830s, and the Ottoman modernizers that replaced them after 1841 encouraged foreign commerce, expanded the cultivation of export crops, and opened the region to European interests. ${ }^{13}$

As foreign economic influence in the area led to increasing diplomatic influence, the European Powers sought to affirm their respective stakes on the Holy Land for reasons of political and ideological expediency. Jerusalem became one of the hubs of European presence in Ottoman Palestine; significant numbers of diplomats, merchants, missionaries, tourists, and pilgrims passed through the city. Resident Europeans cultivated contacts with the local Christian population, and many Ottoman subjects acquired foreign protection or citizenship. New settlements sprung up along the Jaffa Road, and Jerusalem gradually spilled into its rural environs, with new gates opening up on the old city gate walls and the moat being partially filled and covered over. ${ }^{14}$ The German Tempelgesellschaft established its canton in the Baka valley and from the 1870 os onwards, the city began to attract growing numbers of Jewish settlers. ${ }^{15}$

From the perspective of Istanbul, European influence and migration to Palestine represented a threat to Ottoman rule in one of the empire's outlying but strategically and ideologically vital provinces. Under the rule of Sultan Abdülhamid II (1876-1909), the empire sought to counter the challenges it faced on all fronts with a variety of measures. These ranged from carefully balancing the competing interests of the European Powers to radically increasing the strength of provincial garrisons and the resources of provincial administrations. In the empire's Arab provinces, the sultan actively courted public opinion by emphasizing his caliphal title and invoking the religious allegiance that tied the local population with the imperial center. ${ }^{16}$ Within the framework of the Hamidian policies of "fine-tuning," investment in large-scale

13 For the early nineteenth century and the innovations introduced in Palestine under Egyptian rule, see Doumani, Rediscovering Palestine, 42-46, and Yasemin Avcı, Değişim sürecinde bir Osmanlı kenti: Kudüs (1890-1914) [An Ottoman city in the period of transformation: Jerusalem, 1890-1914] (Ankara: Phoenix, 2014), 52-57.

14 Ruth Kark and Michal Oren-Nordheim, Jerusalem and its Environs: Quarters, Neighborhoods, Villages, 1800-1948 (Detroit: Wayne State University Press), 34-35.

15 For the Tempelgesellschaft, see Mahmud Yazbak, "Templars as Proto-Zionists? The 'German Colony' in Late Ottoman Haifa,' Journal of Palestine Studies 28, no. 4 (1999). According to Avcl, Kudüs, 84, the number of Jewish inhabitants increased from two thousand to forty-five thousand from the early nineteenth century to 1914.

16 Selim Deringil, "Legitimacy Structures in the Ottoman State: The Reign of Abdülhamid II (1876-1909)," International Journal of Middle East Studies 23, no. 3 (1991); Ussama Makdissi, "Ottoman Orientalism," American Historical Review 107, no. 3 (2002). 
public projects - from the erection of public buildings to modern infrastructure networks - proved crucial. Though costly, the construction of roads, telegraph lines, and railways was essential for bringing provinces such as Palestine closer to Istanbul and maintaining order and control. Such projects had more than strategic value. The empire could also use them to provide its European rivals and the region's own local elites with evidence that it was capable of independently introducing the benefits of modern civilization to its territories. At the same time, state interventions in areas such as education and welfare broke the monopoly that missionaries largely enjoyed over such vital services. Though the Ottomans frequently lacked the necessary resources and expertise to carry out such projects, by involving European investors in what Soli Shahvar has termed "concession hunting," they could hope to balance out the interests among the different European powers, and ensure that the latter had a stake in the success of the empire's ongoing modernization project. ${ }^{17}$

Already in the 1850 s and 1860s, as the Ottoman Empire was granted access to the European bond markets, the imperial government was presented with proposals for the construction of railway lines and other public works projects in the Levant and Palestine. Most of these proposals focused on connecting the port cities on the Mediterranean coast to Damascus, Aleppo, and Jerusalem, as well as important agricultural areas such as the Hawran. These plans, which often contradicted each other and were always of a speculative character, largely failed to attract the attention of either Ottoman or European investors and were shelved during the 1870s. In 1888, with the Ottoman access to the European bond markets restored, the government issued a concession for the construction of a rail line connecting Jerusalem with Jaffa to Joseph Navon, a local Jewish notable and entrepreneur who had the support of George Franghia, the head engineer of the province. Almost immediately after receiving the concession, Navon sold it to French investors. The Société du Chemin de Fer Ottoman de Jaffa à Jérusalem raised the necessary capital of about 14 million francs, and construction on the line was completed in $1890 . .^{18}$ As a balancing act, the Ottomans gave the concession for the construction of a second regional line, which would connect Damascus to Haifa, to the British Syria Ottoman Railway Company in 189o. The company, however, failed to complete the project in the agreed timeframe and eventually filed for bankruptcy. When

17 Soli Shahvar, "Concession Hunting in the Age of Reform: British Companies and the Search for Government Guarantees; Telegraph Concessions through Ottoman Territories, 1855-1858," Middle Eastern Studies 38, no. 4 (2002).

18 Eduard Pech, Manuel des Sociétés anonymes fonctionnant en Turquie, $5^{\text {th }}$ ed. (Constantinople: Gerard Fréres, 1911), 56-58. 
construction began on the Hejaz Railway in 1900, the Ottoman government decided to construct a branch of the line to Haifa, which was completed in $1905 .{ }^{19}$ The financing of such ambitious technical projects directly from the state budget, assisted only by donations from Muslim communities within and outside the empire, signaled a more assertive policy of reaffirming Istanbul's writ over Palestine and the empire's Arab provinces. The railroad became a physical manifestation of the tenets of Ottoman imperialism in the region, and the stations of its different lines were adorned with a number of public buildings and monuments celebrating the civilizing mission of the sultan. ${ }^{20}$

\section{Urban Elites and the Construction of Urban Infrastructure}

The construction of railways remained a complex undertaking that most often depended on the influx of European capital, or at least relied on European technical expertise. At the same time, the late nineteenth and early twentieth century witnessed the construction of several smaller-scale public work projects across Ottoman Palestine. Some, such as new roads for the transportation of goods, people and troops, and irrigation canals to increase production in areas under cultivation, targeted rural areas. ${ }^{21}$ The Ottoman government was also interested in investing in the infrastructure of the region's rapidly growing towns and providing them with amenities that were becoming increasingly common in other cities in the empire. Beirut and Damascus were both equipped with electric lighting and a tram transportation system in $1907 .{ }^{22} \mathrm{To}$ facilitate commerce and ship traffic in Jaffa, plans for the construction of a new customs house and better port facilities were finally put in motion in $1908 .^{23}$ Because these projects were small in scale, they could be implemented using local resources; engineers from central and provincial administrations, and

19 Jacob Norris, Land of Progress: Palestine in the Age of Colonial Development, 1905-1948 (Oxford: Oxford University Press, 2013), 1-5, 47ff.

20 Michael Talbot, "The Exalted Column, the Hejaz Railway and Imperial Legitimation in Late Ottoman Haifa," Urban History 42, no. 2 (2015).

21 The archives of the Ministry of the Privy Purse (Hazine-i Hassa) contains vast amounts of information on efforts to improve cultivation in the region, and especially in estates that belonged to the sultan, such as 'Ayn al-sultan in Jericho. For examples, see Ottoman State Archives (вОА), нн.THR 27/2 and 325/13.

22 Jens Hanssen, Fin de Siècle Beirut: The Making of an Ottoman Provincial Capital (Oxford: Oxford University Press, 2005), 101-3; Stefan Weber, Damascus: Ottoman Modernity and Urban Transformation (1808-1918), vol. 1 (Aarhus: Aarhus University Press, 2009), 103-11.

23 BOA, T.HNF 693/34, Etude et construction des ports maritimes dans l'empire Ottoman. 
capital raised locally. Like in other comparable Ottoman cities, such projects held great appeal for Jerusalem's elites. The prospect of modernizing the urban fabric, coupled with the potential for financial gains, mobilized local notables. Building on their control over the agricultural economy and extensive kinship networks that expanded throughout and beyond Palestine, notable Jerusalemite families such as the al-Husaynis and the al-Khalidis established themselves as partners of the Ottoman state in the governance of the region. They maintained strong ties to the central administration, either directly or through institutions such as the Jerusalem municipality and the local chamber of commerce. As active participants in agricultural and commercial ventures, they also cultivated good relations with the European commercial and banking institutions active in the region.

By utilizing their contacts, such notable families could acquire concessions for public works projects in their name, then act as intermediaries between the state, European investors, and Jerusalem's general public. On the one hand, by taking control of Jerusalem's urban development, local notables could assert their position against the challenge represented by newly arrived European and Jewish migrant groups. On the other hand, the more the Ottoman state invested in public works in Jerusalem, the better the city's opportunities were for establishing itself as a major commercial and administrative center. In the late nineteenth century, local elites in Ottoman cities such as Beirut, Damascus, and Jerusalem were all lobbying their government to secure the construction of infrastructure in their cities. Consolidating their cities as the main transit stations and railheads in their respective regions was a potent way to secure the monopoly of commerce with their hinterlands at the expense of regional rivals. ${ }^{24}$

The political climate in the empire seemed to favor the initiatives of the notables. During the summer of 1908, the Young Turk Revolution had forced the sultan to reintroduce constitutional rule in the empire. ${ }^{25}$ In autumn 1908 , a group of local entrepreneurs associated with Süphi Pasha and the Jerusalem Chamber of Commerce established the Banque commerciale de Palestine as a means of coordinating investments in the economic development of the

\footnotetext{
24 For the competition between Haifa, Acre and Tripoli for the destination of the railroad, see Norris, Land of Progress, 3 off.

25 The Ottoman constitution of 1876 had been prorogued by Abdülhamid in 1878 . For recent historiographical approaches to the Young Turk Revolution and its impact on Ottoman Palestine, see Yuval Ben-Bassat and Eyal Ginio, "Introduction: The Case Study of Palestine during the Young Turk Era," in Late Ottoman Palestine: The Period of Young Turk Rule, ed. Yuval Ben-Bassat and Eyal Ginio (London: I. B. Tauris, 2011).
} 
region. ${ }^{26}$ The bank, whose shareholders included a cross-section of the city's commercial and land-owning elites, represented an attempt on the part of the local elites to play a more pronounced role in the region's economy, in line with the reassertion of national pride represented by the Young Turk movement in Istanbul. As such, it became involved in infrastructural projects and petitioned the government for a concession for the provision of Jerusalem with water through a modern system of pipes and pumps. The project stirred several debates between the central government, the businessmen associated with the Banque commerciale, and the municipality. The project eventually became mired in controversy when the municipality broke its contract with the Banque commerciale and awarded the concession to a German engineer, Carl Francke. ${ }^{27}$ A similar initiative to introduce street lighting in the city was blocked because of a dispute between the municipality and European consuls. The latter refused to acquiesce in the taxation of non-Ottoman residents to help finance the cost of the project. ${ }^{28}$

Within this framework, in January 1909, the provincial administration in Jerusalem was presented with a petition for a concession to construct an electrical tramline in Jerusalem with provisions to construct a similar line in Jaffa. The petition also called for the provision of electric lighting in the two cities. The Jaffa-Jerusalem Railway had attempted to secure a similar contract in 1907, but this plan had been shelved after the municipality proved unable to contribute to the cost of construction. ${ }^{29}$ The new petition was launched in the name of the Banque commerciale, specifically its founding members; al-Hajj Yusuf Wafa, who was the chamber of commerce president, Isma'il al-Husayni, Albert Antébi, and Selim Ayub. ${ }^{30}$ The petitioners submitted topographic plans for the two projects: the Jerusalem network (fig. 24.1) involved three lines that

26 Michelle U. Campos, Ottoman Brothers: Muslims, Christians, and Jews in Early TwentiethCentury Palestine (Stanford: Stanford University Press, 2011), 173-77.

27 Ibid., $177-78$. For a broader study of Jerusalem's chronic water shortages, and attempts to provide the city with water, see Vincent Lemire, La soif de Jerusalem: essai d'hydrohistoire (1800-1948) (Paris: Publications de la Sorbonne, 2010). For the dispute between the chamber of commerce and the municipality, set against the backdrop of the rivalry between the al-Husayini and the al-Khalidi families, see Schölch, Palestine in Transformation, 247-49.

28 Lemire and Avcl, "De la modernité administrative a la modernisation urbaine: Une réévaluation de la municipalité de Jérusalem, 1867-1917," in Municipalités méditerranéennes: les réformes urbaines ottomanes au miroir d'une histoire comparée (Moyen-Orient, Maghreb, Europe méridionale), ed. Nora Lafi (Berlin: Klaus Schwarz, 2005), 103-4.

29 Campos, Ottoman Brothers, 91.

$30 \quad$ BOA, T.HFN 693/34, 5 Mayıs 1325 [May 18, 1909]. 
would connect the walled city to the growing suburban settlements. All three lines terminated at Jaffa Gate, which had begun to evolve into the administrative center and the cultural heart of Jerusalem. ${ }^{31}$ Line A would move westward along the Jaffa Road, past the Muslim cemetery, and would terminate at the Ottoman hospital, covering a distance of 2,180 meters. ${ }^{32}$ Line B would connect the city to the Jaffa-Jerusalem Railway station, at Baq'a, passing to the north of Birkat al-Sultan and along the Bethlehem Road, for a total length of about 1,340 meters. Finally, Line $C$ would also terminate at the train station, this time from the south, after passing by the German colony. ${ }^{33}$ The plan for Jaffa (fig. 24.2) proposed the construction of a line between the city's rail station and the European quarter to the south of the city, with a smaller line branching off to the port and the customs house. ${ }^{34}$

The petitioners entered negotiations with the provincial government on the issues of the convention and the scope of the concession, which would be based on the recent concession for the construction and operation of the electric trams and lighting of Salonika and Beirut. ${ }^{35}$ According to the draft convention, the concession would have a duration of fifty years, after which point it would pass to the respective municipal authorities. The concessionaires pledged to establish a joint stock company, in accordance with Ottoman corporate law, to direct the construction and operation of the two projects. The company was obliged to begin construction within six months of the finalization of the contracts and the maps, and the projects had to be operation within five years of that date. The company would be exempt from dues on any equipment and material necessary for the construction imported into the region, as well as from property tax on its buildings. The Ottoman government reserved the right to any antiquities discovered during construction. Company personnel would have to be Ottoman subjects, and those coming into contact with the public had to be conversant in the local idiom (lisann-i mahaliye). Both sides agreed that the company would be paid 30 centimes for every kilowatt-hour

31 Avcl, Kudüs, 245ff.

32 Ibid., 236-37.

33 BOA, T.HFN 693/34, Projet de Tramways aux abords de la ville de Jerusalem - Plan d'ensemble du réseau. For the German colony of Jerusalem, see Yehoshua Ben-Arieh, Jerusalem in the 19th century: Emergence of the New City (Jerusalem: Yad Izhak Ben-Zvi; New York: St. Martin's Press, 1986), 127-32. 
of electricity consumed, and the prospective concessionaires deposited 1,000 Ottoman liras as guarantee. ${ }^{36}$

In May, the provincial council (meclis-i idāre) approved the draft convention and petitioned the Ministry of Commerce and Public Works in order to approve the petitions and launch the project. ${ }^{37}$ The resolution issued by the council vouched for the dependability of the concessionaires and their ability to cover the costs of construction, which were then estimated at 20,00o liras. ${ }^{38}$ The council also cited the necessity of endowing the two cities with a tram system, as the absence of modern means of transportation was detrimental to the conduct of commerce and to further urban expansion. ${ }^{39}$

Having secured the backing of the provincial authorities, al-Hajj Yusuf Wafa continued to pressure the municipal authorities for their endorsement and support for the project. In a memorandum to the provincial governor, the president of the chamber of commerce defended the clauses containing allowances on behalf of the company. He also requested the governor's mediation to convince the municipality to partially cover the cost of construction specifically paying for the paving of the streets the tramlines would pass through. According to him, the construction and operation of a system of modern transportation and electric lighting seemed straightforward in Ottoman port-cities such as Izmir, Salonika, and Beirut, or even Damascus, which had ample access to water. In Jerusalem, however, located far from the coast, where water was scarce, costs would be higher than anticipated. ${ }^{40}$ Without the support of the municipality, Wafa expressed doubts about the feasibility of the project and the ability of the concessionaires to fully finance it. To that end, he submitted a series of additions to the original convention which in his view would maximize the economic utility of the line, as well as its benefits to the inhabitants of Jerusalem and the local economy. He proposed that the convention include provisions for the extension of the tramline so that it would reach the Mount of Olives to the east and Bethlehem to the south within eight years. That branch of the network was to operate both a passenger and a freight

36 BOA, т.HFN 693/34, Küds-i Şerif ve Yafa Tramvaylar Muḳāvelenāmesi.

37 For the representative functions of the provincial council, see Campos, Ottoman Brothers, 166-68.

38 The annual municipal budget was 12,000-14,00o liras just before the war. Avcı and Lemire, "De la modernité," 105.

39 BOA, T.HFN 693/34, 5 Mayıs 1325 [May 18, 1909].

40 Besides pointing to the ongoing dispute about the water supply concession of Jerusalem, Yusuf Wafa was also probably suggesting that the electricity would be produced not by gas or oil, but in a steam plant. 
service, thus easily connecting the rural producers of the environs of Jerusalem with the city's markets and train station. ${ }^{41}$ The company would pledge to procure wagons wide enough for the needs of the passengers, divided into two classes, with separate spaces for female family members (haremlere mahșuss $).{ }^{42}$ Finally, the ticket price was set at 20 paras for first class and 10 paras for second class travelers, with police and military officers enjoying a 50 percent discount. ${ }^{43}$

\section{Conclusion: End of the Line?}

In the end, Wafa's concerns proved well-founded. The concessionaires were unable to secure the backing of the municipality or find other investors interested in the project, and withdrew their offer. In 1914, the Ottoman central government attempted to relaunch the project along the same terms, using the draft convention of 1909. The new plan proposed the issue of a single concession for all three stalled infrastructure projects of Jerusalem: the tram, the street lighting, and the modernized water system. A preliminary convention was signed between the Jerusalem municipality and Evripidis Mavrommatis, a Greek Ottoman from Istanbul, but the outbreak of World War I put the project on hold. ${ }^{44}$

This vignette from the history of late Ottoman Jerusalem illustrates the extent to which the provincial authorities and the elites wanted to transform their city. The inspiration for the modernization of the urban fabric did not necessarily come from the great capitals of Europe, but rather from the burgeoning urban centers of the Ottoman Empire, that is, cities such as Istanbul, Salonika, Izmir, and Beirut, which had seen a rapid transformation in the preceding decades. The developments that followed the revolution of 1908 gave certain notables and businessmen of Jerusalem the opportunity to attempt to put in motion their own vision for their city. Represented on the board of the newly founded Banque commerciale, and with the support of Süphi Pasha and the provincial government, they articulated their business plans

\footnotetext{
41 BOA, T.HFN 693/34, 23 Mart 1325 [April 5, 1909].

42 For the negotiation of physical contact and gender within the enclosed space of a tram wagon, see James Ryan, “'Unveiling' the Tramway: The Intimate Public Sphere in Late Ottoman and Republican Istanbul," Journal of Urban History (published online April 2016), accessed February 2, 2018, DOI:10.1177/oog6144216641070.

43 BOA, T.HFN 693/34, 23 Mart 1325 [April 5, 1909].

44 Avc1, "Jerusalem and Jaffa in the Late Ottoman Period: The Concession-Hunting Struggle for Public Works Projects," in Late Ottoman Palestine: The Period of Young Turk Rule, ed. Yuval Ben-Bassat and Eyal Ginio (London: I. B. Tauris, 2011), 91-92.
} 
in the discourse of technical modernization and urban development. They also stressed the need for Jerusalem and Jaffa to "catch up" with other cities of the region in terms of state investment and infrastructure. From this perspective, the introduction of tram transportation in the two cities (similar to the attempts to construct a modern water supply system and street lighting in Jerusalem) would facilitate further development and ensure that they acquired the technical artifacts of modern civilization that characterized Ottoman cities at the turn of the century.

The eventual failure of these endeavors, however, also reveals both the relative disadvantages of Jerusalem compared to the larger Ottoman cities as well as a general crisis of the political and economic model that had sustained the development of the empire's cities. Beyond Jerusalem's relative isolation, which made the costs of construction higher, the atypical presence of non-Ottomans in the city - be they European residents, Templar settlers or Jewish migrants and the protection these groups enjoyed from Ottoman interference thanks to the strong presence of the European diplomatic missions, meant that the local Ottoman institutions were relatively weak and enjoyed limited resources. At the same time, the initiatives of the Banque commerciale and the chamber of commerce were directly challenged by the Jerusalem municipality, which undermined the common front of local notables and the provincial administration with regard to Istanbul. Rather than a result of a family feud between the al-Husayni and al-Khalidi clans (that is, a subjective failing of the Ottoman elites of Jerusalem), the dispute between these institutions should be attributed to the novel political conditions in the period following the Young Turk Revolution. The reintroduction of constitutional rule brought along the concept of mass politics, turning local institutions from sites of manufacturing consent between the state and local notables to sites of contest between different political groupings. ${ }^{45}$ In these conditions, the elite arrangements that had spearheaded urban development could not be maintained. ${ }^{46}$ Large-scale investment in infrastructure would resume after the end of the war, but in the very different political and economic environment of the British Mandate.

45 This argument is more broadly expressed in Campos, "Making Citizens, Contesting Citizenship in Late Ottoman Palestine," in Late Ottoman Palestine: The Period of Young Turk Rule, ed. Yuval Ben-Bassat and Eyal Ginio (London: I. B. Tauris, 2011).

46 The collapse of cohesion among Ottoman elites as a result of new political challenges was not unique to Jerusalem, but can be observed in cities throughout the empire. For the example of Izmir, see Vangelis Kechriotis, "Protecting the City's Interest: The Greek Orthodox and the Conflict Between Municipal and Vilayet Authorities in İzmir (Smyrna) in the Second Constitutional Period," Mediterranean Historical Review 24, no. 2 (2009). 